\title{
Earnings Announcement Premia and the Limits to Arbitrage*
}

\author{
Daniel A. Cohen \\ Leventhal School of Accounting \\ Marshall School of Business \\ University of Southern California \\ Los Angeles, CA 90089 \\ Aiyesha Dey \\ Thomas Z. Lys ${ }^{* *}$ \\ Shyam V. Sunder \\ Kellogg School of Management \\ Northwestern University \\ Evanston, Illinois 60208
}

December 27, 2004

* A previous version of this paper was entitled: Blinded by the Light: Are Earnings Announcements worth the Risk? We would like to thank Yonca Ertimur, Tom Fields, Emre Karaoglu, Margaret A. Neale, Doug Skinner (the editor), Linda Vincent, an anonymous referee and seminar participants at the 2004 meeting of the American Accounting Association, the Massachusetts Institute of Technology, the University of Illinois at Chicago, and the Zell Brown Bag Seminar Series at the Kellogg School for helpful comments on previous drafts. Financial support from the Zell Center for Risk Research at the Kellogg School is gratefully acknowledged. All remaining errors are our own responsibility.

** Corresponding Author (847) 491-2673, tlys@kellogg.northwestern.edu 


\title{
Earnings Announcement Premia and the Limits to Arbitrage
}

\begin{abstract}
We document that earnings announcement-day premia persist beyond the sample period of earlier studies, over different disclosure environments and remain robust to the refinement of using the expected announcement day rather than the actual announcement day. A portfolio of announcing firms yields returns in excess of the corresponding risk. Excluding announcers from a well-diversified portfolio, while reducing the standard deviation of that portfolio, also reduces its Sharpe ratio, indicating that this strategy results in a less favorable risk-return trade-off. Finally, we provide evidence that the premia are dramatically reduced when the announcement risk is reduced through preannouncements. In addition, we document that the continued presence of this premia is likely to result from limits to arbitrage. These findings are consistent with the view that the announcement period returns are likely to represent compensation for announcement risk.
\end{abstract}

\section{Introduction}

Prior literature has documented the existence of abnormal returns around predictable news announcements (Penman, 1984; Kalay and Lowenstein, 1985; Chari, Jagannathan and Ofer, 1988), and these abnormal returns remain after controlling for the increase in systematic risk in the announcement window (Ball and Kothari, 1991). Assuming investor rationality and mean-variance pricing, investors would require announcement premia when: (1) the announcement day is known in advance or is predictable, and (2) the risk is non-diversifiable after taking into account the increase in risk resulting from the announcement. ${ }^{1}$

\footnotetext{
${ }^{1}$ Robicheck and Myers (1966) illustrate this phenomenon with the following story: A ship sets out on a two-year voyage in search of gold. At its departure, the prices of all financial claims on the payoffs of this journey reflect all the available information. Suppose no information reaches the market while the ship is away. Until the point the ship reaches the port, expected return on all financial claims related to the payoffs from the journey will be free of additional risk, because there is no information that would lead investors to change their valuations. Hence, during the voyage, the investment should earn the risk-free rate. However, the uncertainty is resolved once the ship returns with cargo. Therefore, if the risk were not diversifiable, the expected return would be higher on the day the market receives information about the claims' likely payoff.
} 
On the surface it would appear that the announcement risk should be diversifiable and not reflected in higher returns. For example, Fama (1986) documents that the risk of a portfolio converges rapidly towards that of a fully diversified portfolio as the number of securities increases, and that the number of securities necessary to achieve diversification is relatively small, typically less than 30 . Thus, announcement risk should be diversifiable, given that (i) relatively few securities announce earnings on a given day, (ii) the number of securities traded on US stock exchanges exceeds 7000 , and thus announcers would make up a miniscule fraction of a well-diversified portfolio, and (iii) we find relatively little industry clustering of earnings announcement days. ${ }^{2}$ Jointly, these factors suggest that the announcement risk should be diversifiable and reinforces the idea that the presence of continuing announcement premia is a puzzle.

The purpose of this paper is three-fold. First, we extend the prior literature on the announcement risk premium by examining the existence of the announcement premium over time, after controlling for the timing of the announcements (whether the announcements were early, on-time, or late), and the changes in the disclosure environment (by controlling for pre-announcements made by firms). Second, we examine the risk-return tradeoff investors face in light of the non-diversifiability (or the lack thereof) of announcement risk. Finally, we test whether the limits to arbitrage explain the continued existence of the announcement premium.

Consistent with prior research, we find a significant announcement premium when we use the firm's non-announcement period returns as well as when we use non-announcing firms' returns in the announcement period as benchmarks. Specifically, the average

\footnotetext{
${ }^{2}$ For example, within a two-digit SIC industry classifications, we find on average only 5 firms announcing on the same day.
} 
return in the expected announcement period (days $-1,0$, and +1 relative to the expected earnings announcement day) for firms that announced on time or later than the expected date, is about 0.05 percent when the firm is used as its own control, and 0.01 percent when the returns of non-announcers in the announcement period of a firm is used as a control.

The presence of this announcement premium is significant for several reasons. First, it establishes the continued existence of a premium in spite of published research identifying this profit opportunity, the latest of which was published by Ball and Kothari in $1991 .^{3}$ Second, we use the expected announcement date rather than the actual announcements dates used in prior literature to document the announcement premium. Therefore, our results do not suffer from a selection bias arising from timing of the earnings announcements - early, late or on-time announcements. Third, we investigate the announcement premium for a subset of firms that issued earnings pre-announcements - thus effectively reducing (or even eliminating) the earnings announcement risk. We find that pre-announcements eliminate the announcement premium. Thus, this result is consistent with the hypothesis that the increased return on earnings announcement dates is indeed related to announcement risk.

Turning to the question of whether the announcement premium compensates for the increased risk, we find that portfolios comprising announcer firms earn a significant excess return (Jensen's alpha) of between 0.038 percent and 0.053 percent per day. Further, we show that excluding announcing firms from an otherwise fully diversified portfolio results in a decline of the average portfolio standard deviation by 3.1 percent but

\footnotetext{
${ }^{3}$ The sample period of Ball and Kothari (1991) ended in the first quarter of 1988.
} 
results in lower Sharpe ratios. Thus excluding announcing firms results in a less favorable return-risk tradeoff. ${ }^{4}$ Jointly, these results lead us to the conclusion that earnings announcements returns are "worth" the risk.

In considering why these premia persist, our evidence indicates that limits to arbitrage prevent the announcement period abnormal returns from being arbitraged away. Specifically, we find that the premium is positively associated with the costs of arbitrage, including idiosyncratic risk and the bid-ask spread. We find weak evidence supporting a negative association between the premium and the float on announcement days consistent with arbitrage being more likely when a sufficient number of shares are available for trading. We also find that the premium is higher on days when greater concentrations of firms announce their earnings - consistent with the hypothesis that arbitrage capital is limited. Finally, our results indicate a negative association between the announcement premia and the trading volume on announcement days. We interpret this result as supportive of the hypothesis that when arbitrage activity is high, premia are low.

The remainder of the paper is organized as follows. Section 2 provides an overview of the related literature and Section 3 discusses the research questions. Section 4 describes the data used in the analysis. Section 5 contains a detailed analysis of the announcement premia. Specifically, in this section we analyze the magnitude of the announcement premia after controlling for the timing of the announcements, the effect of the changing disclosure environment on the announcement premia, and the persistence over time of the announcement premia. Section 6 presents an analysis of whether

\footnotetext{
${ }^{4}$ Also, the Sharpe ratio of the portfolio of announcing firms exceeds the Sharpe ratio of the portfolio of non-announcing firms once sufficient diversification is present in the announcer portfolios.
} 
earnings announcements are worth the risk, and Section 7 explores limits to arbitrage as an explanation for the continued existence of the announcement premia. Finally, Section 8 concludes.

\section{Related Research}

Chari, Jagannathan, and Ofer (1987) and Ball and Kothari (1991) document that unconditional on the earnings information, returns on earnings announcement days are higher than on non-earnings announcement days. A similar effect for dividend announcement days has been documented by Kalay and Loewenstein (1985).

According to Ball and Kothari (1991), while scheduled earnings announcements resolve some uncertainty about future cash flows (the "uncertainty resolution hypothesis"), the increased flow of information also increases the variability of returns during these announcements. They hypothesize that the arrival of new information causes the systematic risk (beta) to increase leading to the observed higher expected returns during the earnings announcement period. Therefore, announcing firms will have higher return variances, betas and expected returns. In their empirical tests, they find significant abnormal returns $(0.066$ and 0.078 percent on days -1 and 0 respectively, where day 0 represents the actual earnings announcement day). Ball and Kothari find that a significant portion of announcement period abnormal returns remains unexplained even after they control for the increase in the $\beta$-risk during earnings announcement periods. The presence of these abnormal returns is a puzzle, but Ball and Kothari do not investigate potential explanations for this puzzle beyond documenting that the abnormal returns are negatively correlated with firm size. However, the use of actual 
announcement dates complicates the interpretation of the results. The reason is that a significant fraction of firms announce earnings prior to their "expected" announcement date. As a result, these announcements are unanticipated and, as a result, there should be no announcement risk premia on those dates. Moreover, Chambers and Penman (1984) document that early announcers tend to be firms with good news, while late announcers tend to be firms with bad news. Thus, Ball and Kothari combine announcement premia and the response to the news contained in early and late announcements, complicating the interpretation of their results.

A few empirical studies have documented results that conflict with the presence of an earnings announcement-day premium. Peterson (1990) finds that the seasonal patterns of returns for firms reporting earnings on a given day are not stronger than those for firms not announcing earnings on a given day. Brown and Kim (1993) provide evidence suggesting that earnings announcements of small firms are associated with positive abnormal returns due to concurrent non-earnings announcements made by these firms, not to the earnings announcements of small firms' per se.

In summary, while the preponderance of evidence supporting the presence of higher returns on predictable disclosure events suggests that investors require an announcementday premium, this finding is not without controversy. Specifically, given the large number of firms, it is hard to imagine that opportunities for diversification of this risk would not eliminate, or at least mitigate, any need for an announcement-day premium.

One alternative reason for abnormal returns around earnings announcements identified by prior research is attributed to the signal value of the timing of the announcements. For example, Chambers and Penman (1984) find negative abnormal 
returns on annual report announcement dates that are unexpectedly late. This finding is interpreted as an indication that investors interpret the failure to report on time as a forecast of bad news. McNichols (1988) finds that return distributions are more negatively skewed on earnings announcement dates than during non-announcement periods. One explanation for this result provided by McNichols is that more extreme bad news is disclosed by mandatory earnings reports than by other discretionary information sources. This conjecture is supported by studies such as Patell (1976), Penman (1980) and Waymire (1984), which show that management earnings forecasts are more optimistic than analysts' earnings forecasts. Lev and Penman (1990) also document evidence of a 'screening motive' among firms where earnings forecasts are used by firms with 'good news' to screen themselves out from other firms. In contrast, Skinner (1994, 1997), Kaznik and Lev (1995) and Soffer, Thiagarajan, and Walther (2000) argue that bad news firms announce early to mitigate litigation risk. Begley and Fischer (1998) assess the relation between earnings news and earnings announcement timing in the period 1983-1992. They find that while early announcements are associated with good news relative to late announcements over the sample years, the relationship is not strictly monotonic.

One explanation for the persistent announcement premium effect found in the literature may be attributed to the limits to arbitrage. According to Shleifer and Vishny (1997), the effect of arbitrage is to bring security prices to their fundamental values and make markets efficient. According to Scholes (1972), the arbitrageur would buy (sell) an under (over) priced stock and simultaneously short (long) a perfect substitute. In theory arbitrage requires no capital and is essentially risk free since the arbitrageur buys the 
cheaper security and sells the expensive one, his net future cash flows are zero for sure and he makes all his profits upfront. However there are two major barriers to execution of costless arbitrage in practice. First, as Mashruwala, Rajagopal and Shevlin (2004) point out that for a riskless hedge to exist, the arbitrageur needs to find close substitute stocks whose returns are highly correlated with the returns of the firms subject to anomalous mispricing. However, identifying such substitutes is a difficult task in practice. In their study, they find that the well documented "accruals anomaly" is persistent since it is difficult to arbitrage. Secondly, as Shliefer and Vishny (1997) point out, frictions and risks in execution of the arbitrage in practice results in "risk arbitrage" that requires substantial commitment of capital on part of arbitrageurs. In turn, arbitrageurs may have capital constraints or may be forced to raise capital from investors who may not have the required appetite to sustain risk positions. These factors deter arbitrage activities and can lead to persistent anomalous returns in the market.

\section{Research Questions}

Our first research objective is to extend prior research on identifying the conditions under which an announcement risk premium exists. The sample period of the most recent research on announcement-risk premia (Ball and Kothari, 1991) ends in the first quarter of 1988. However, significant changes in the information environment occurred since the late 1980s. Specifically, there has been an increase in voluntary disclosures outside the required periodic disclosures, such as earnings pre-announcements. Because pre-announcements reduce the announcement risk and are likely to reduce earnings announcement premia, we expect pre-announcing firms to have a smaller announcement 
period return. Thus, the occurrence of pre-announcements provides a natural experiment in which to test whether the increased return on earnings announcement dates relate to earnings-announcement risk.

In addition to pre-announcements, we also examine the effect on announcement premia of the information content of earnings announcements, relative to all other sources of information. Specifically, we investigate whether periods with a large number of other information releases are associated with higher or lower announcementperiod premia.

Several aspects of the existing research on the announcement-day premium present opportunities for further analysis and modifications. First, prior studies documenting the announcement-day premium use the actual announcement dates rather than the expected announcement dates (Chari et al, 1987, Ball and Kothari, 1991). However, one precondition for an announcement premium to exist is that the announcement date is known in advance or is predictable. We refine the analysis of the earnings announcement premium by controlling for the timing of the announcements.

The presence of a continued and robust earnings announcement premium leads to our next research question: how much risk do earnings announcements add to the risk of a well diversified portfolio? We study whether the increased risk on earnings announcement days is justified by increased return on those days. To answer this question we examine how much excess returns can be earned by adding announcing firms to a portfolio of non-announcing firms.

Finally, we investigate why the announcement premia are not eliminated by arbitrage. We explore this issue by considering whether limits to arbitrage can explain the 
continued existence of the announcement day premium. Specifically, we explore whether idiosyncratic risk, bid-ask spreads, float (average trading volume scaled by the average number of shares outstanding), trading volume, and concentration of announcing firms is related to the earnings announcement premium.

Arbitraging announcement risk requires undiversified positions. As a result, arbitrage portfolios will be more risky for firms with greater idiosyncratic risk. Therefore, arbitrageurs are likely to take smaller positions in firms with high idiosyncratic risk, resulting in higher announcement-period premia for those firms.

Bid-ask spreads reflect a large portion of the round-trip transaction costs associated with arbitrage and we expect the (un-arbitraged) announcement premia to increase in the bid-ask spread. Float measures the number of shares available in the market place. The higher the float, the easier it is for arbitrageurs to assume and unwind their positions. Trading volume measures the impact of arbitrageurs' trading market prices and we expect a negative relation between trading volume and announcement risk premia. This is in contrast to Beaver's (1968) hypothesis - where volume is a measure of the arrival of information, thus implying a positive relation between volume and announcement period return.

Finally, since arbitrage capital is likely to be limited, the greater the concentration of firms announcing on a given date the higher the un-arbitraged announcement-risk premium. Evidence supporting the limits to arbitrage theory also implies that the announcement risk premia is likely to persist. 


\section{Data}

Table 1 describes the sample selection criteria. Quarterly earnings announcement dates are collected from the COMPUSTAT quarterly file for the period 1978 to 2001 to yield a maximum of 96 quarters for each of the sample firms. We collect all firms with a December fiscal year and available quarterly earnings announcement dates on COMPUSTAT, resulting in 12,377 firms and 297,426 firm-quarter observations. We only retain firms with at least 10 firm-quarter observations, resulting in 8,493 firms and 275,820 firm-quarter observations. Finally, after merging the COMPUSTAT sample with CRSP daily files, we retain 7,260 firms and 227,281 firm-quarters.

We collect earnings announcement dates from COMPUSTAT. As per COMPUSTAT, this date corresponds to "The date in which quarterly earnings and earnings per share figures are first publicly reported in the various news media (such as the Wall Street Journal or newswire services)." ${ }^{, 5}$ As a result, the information may have been impounded into security prices on day -1 or 0 for events where the announcement date is from the news media and on day 0 or +1 when the earliest date is from newswire services. Therefore, we define the earnings announcement period as the three days centered on the COMPUSTAT earnings announcement date (days $-1,0$, and +1 ).

For our analyses on the effect of the disclosure environment on the announcement premium, we gather data on pre-announcements of quarterly earnings. The preannouncement data is obtained from the Company Issued Guidance (CIG) database maintained by First Call. First Call gathers data about earnings pre-announcements from

\footnotetext{
${ }^{5}$ Ball and Bartov (1995) state that COMPUSTAT relies on data sources such as, the Wall Street Journal, for earnings dates. However they suggest that the errors may be "small in number".
} 
press releases and interviews by company officials. ${ }^{6}$ An analysis of the database shows that the data is available on a widespread basis from 1998, although First Call claims to have data going back to 1990 . We restrict our pre-announcements sample to observations over the period 1998 to 2001 because the data for prior periods is less complete. This sample selection yields 70,073 firm-quarter observations for 5,178 firms. Of these, 46,184 firm quarters representing 5,121 firms had pre-announcements.

\section{Analysis of the Announcement Risk Premia}

Prior literature (Chari and Jagannathan, 1987; Ball and Kothari, 1991) has documented the existence of earnings announcement premia using the actual earnings announcement date. However, their approach suffers from ex-post conditioning of the event date. Using actual dates adds noise to the measurement of the premia because the timing of the announcement per se may convey information. For example, good news firms may announce early, while bad news firms may announce late (Penman, 1987; McNichols, 1988). We begin the empirical analysis by investigating the magnitude of the earnings announcement premia as a function of the timing of announcements, i.e., we first examine the abnormal returns for early, on-time and late announcers.

\subsection{Premia Relative to the Timing of Announcements}

We estimate the expected earnings announcement date for each firm in each quarter using the procedure described in Appendix I. Briefly, we estimate a firm-specific model to estimate the expected announcement date. Using this procedure, we classify firm-

\footnotetext{
${ }^{6}$ Other studies that have used the database are Soffer, Thiagarajan and Walther (2000) and Cotter, Tuna and Wysocki (2002).
} 
quarters as early announcements, on-time announcements, and late announcements. Ontime announcements are those which occurred in the expected announcement periods (consisting of the three-day period centered on the expected announcement date). ${ }^{7}$ Late announcements are those which occurred subsequent to the expected announcement periods and early announcements are those which occurred prior to the expected earnings announcement periods.

We form portfolios of each group of firms and compute the returns over two periods: the expected earnings announcement day (day 0 ) and the expected earnings announcement period (days $-1,0$ and +1 ). We obtain similar results for the one-day announcement periods as for the three-day announcement periods and, for brevity, we only report and discuss the results for the three-day announcement periods.

To investigate the existence and the magnitude of the earnings announcement premia, we use two benchmarks. First, for each firm $j$ and quarter $q$ we subtract the mean return in non-announcement periods. This first benchmark uses the firm as its own control. Since there is a significant clustering of announcement dates in calendar time, we also use the returns on all non-announcing firms on the announcer's date as a second control: for each announcement in period $t$ and quarter $q$, we compute the mean daily return for firms that did not announce. While our major results are invariant to the specific benchmark, the following trade-off exists. Using the firm as its own control (the first benchmark) has the advantage that it is likely to provide a better control for risk to the extent that firms within an industry may announce in close proximity (and hence the nonannouncer portfolio is likely to consists of firms from other industries). However, the

\footnotetext{
${ }^{7}$ As a sensitivity check, our results remain qualitatively unchanged when we define on-time announcements as those occurring on the expected announcements date (as opposed to the three-day window centered on the expected announcement date).
} 
second benchmark (using non-announcing firms as a benchmark) controls for market movements.

Table 2 reports the announcement premium relative to the two benchmarks. For the entire sample, on expected announcement periods we find an announcement premium of 0.05 percent $(t=2.99)$ using the firm as its own benchmark and 0.01 percent $(t=3.11)$ using non-announcers as a benchmark.

Firms announcing prior to the expected date (that is the actual announcement occurred prior to the expected announcement period) earned a premium on the expected announcement date using the firm as its own benchmark (abnormal return 0.05 percent, $t$ $=2.49$ ). Although the magnitude is small, this result is a bit surprising, since these firms have already announced, we should not observe any abnormal return on the expected announcement date. However, the magnitude of the excess return on the expected announcement date is not significant when we use non-announcing firms as the benchmark $(-0.00$ percent, $\mathrm{t}=-0.93)$.

On the actual announcement date, we find that early announcers had an announcement premia of 0.29 percent $(t=15.18)$ relative to their non-announcement returns, and 0.14 percent $(\mathrm{t}=14.73)$ relative to non-announcing firms in the same period. Overall, these results are consistent with our expectations, since prior research has shown that firms announcing early tend to have good news (Chambers and Penman, 1984; McNichols, 1988). Firms announcing on time have an announcement premia of 0.13 percent $(t=5.49)$ relative to their non-announcement returns, and 0.02 percent $(t=2.87)$ relative to the return of other firms that did not announce in that window. ${ }^{8}$

\footnotetext{
${ }^{8}$ Note that the expected and actual announcement dates are identical for firms announcing on time.
} 
Late announcing firms have a negative, but insignificant, announcement premia both relative to their own non-announcement returns $(-0.00$ percent, $t=-0.31)$ and relative to the returns of non-announcing firms $(-0.00$ percent, $t=-0.29)$ in the expected announcement window. In their actual announcement window, late announcers have insignificant negative announcement premia relative to their non-announcement return $(-0.00, t=-0.94)$ and a significantly negative announcement premia relative to nonannouncing firms $(-0.00, \mathrm{t}=-6.42)$.

To analyze the magnitude of the earnings announcement risk premia, we combine ontime and late announcing firms. The reason for this is to avoid a selection bias, as late announcing firms cannot be identified ex-ante. In the expected announcement windows, the combined sample of on-time and late announcers have an announcement premia of 0.052 percent $(t=4.37)$ relative to their non-announcement returns, and 0.008 percent $(t$ $=5.14)$ relative to the return of non-announcing firms. The corresponding numbers for the actual announcement windows are 0.052 percent $(t=2.53)$ and 0.008 percent $(t=$ 4.20) respectively.

To summarize, for the expected announcement periods, we find positive premia when firms announce on time, zero abnormal returns when they announce early (except when we use the firm as its own benchmark), and negative abnormal returns when they announce late (although the latter results are not statistically significant). For the actual announcement periods, we find positive returns for early announcers and negative returns for late announcers (except when we use the firm as its benchmark). Thus, these results are generally consistent with both the announcement risk hypothesis and the ChambersPenman hypothesis. 
Our announcement premia are generally consistent with results reported in much of the literature. For instance, Beaver (1968) finds that for 143 firms during 1961-1965, the average risk-premium in the annual earnings announcement week was around 4 times the average rate of return in other weeks. For the 1976-1984 period, Chari, Jagannathan and Ofer (1987) document that for the smallest $10 \%$ of the sample firms, $16 \%$ of the average annual return occurs on the 8 days in a year corresponding to the two-day windows surrounding the four quarterly earnings announcement days. ${ }^{9}$

However, our results also indicate that the announcement premia documented in prior research (relying on the actual as opposed to the expected announcement periods) are overstated, as the Chambers-Penman effect (good news firms announce early, bad news firms announce late) is larger for early announcers than for late announcers. Specifically, the premia for the entire portfolio is much higher when computed for the actual announcement periods as compared to the expected announcement periods $(0.014$ percent compared to 0.05 percent when the firm is used as its own benchmark, and 0.06 percent compared to 0.01 percent when non-announcers are used as a benchmark, respectively). As expected, a large component of the premia on the actual announcement period is contributed by the early announcers ( 0.29 percent when the firm is used as its own benchmark and 0.14 percent when non-announcers are used as a benchmark respectively).

The above evidence underscores the importance of using expected versus actual announcement periods while testing for the announcement premia. To address this issue, we conduct our subsequent tests on announcement premia for two subsamples: the

\footnotetext{
${ }^{9}$ In a closely related research, Kalay and Loewenstein (1985) show that an equally-weighted portfolio of all dividend announcements made by 302 firms during July 1962 through December 1980 yields excess returns of $0.4 \%$ over the four day event period commencing on the dividend announcement day.
} 
sample of on-time announcers only, i.e., those firms whose actual announcement periods coincided with their expected announcement periods, and the sample of on-time and late announcers only, i.e., those firms whose actual announcement periods either coincided with or were after their expected announcement periods.

Overall, even after controlling for the timing of announcements, we find compelling evidence for the existence of an announcement risk premium. Our next goal is to investigate the effect of the changing disclosure environment on the announcement risk premia. Specifically, we provide two tests of the impact of changes in the disclosure environment on the earnings announcement premia: we analyze the effect of earnings pre-announcements, and the information content of earnings announcements on the announcement premia. This evidence is presented next.

\subsection{The Effect of Changing Disclosure Environment on Announcement Risk Premia}

As indicated above, the disclosure environment has changed significantly over the sample period. One of the significant changes has been the increased tendency of firms to make earnings pre-announcements. In the presence of pre-announcements we would expect to see a reduction in the earnings announcement premia since the news is no longer a complete surprise. In other words, if the return documented in Table 2 is an announcement-risk premium, then that premium should be lower (or absent) for firms that pre-announced earnings (as there is reduced or no disclosure risk left). We begin by investigating whether pre-announcements result in lower earnings announcement premia. We also analyze whether the announcement period premia are related to changes in the information content of earnings, relative to all other sources of information. 
To analyze the effect of pre-announcements on the announcement premia, we gather data in the date of pre-announcements from First Call for the period 1998 through 2001. The results are reported in Table 3A. We first analyze the announcement period returns for on-time and late announcing firms in the 1998-2001 period (Row 1): For firms that issued pre-announcements, the announcement period premium is 0.06 percent $(t=2.48)$ using the firm as its own benchmark and 0.05 percent $(t=2.38)$ relative to nonannouncing firms. In contrast, the returns are 0.14 percent $(t=4.08)$ and 0.11 percent $(t$ $=3.53$ ) for firms that did not issue pre-announcements in the same period. Row 3 reports that the differences between rows 1 and 2 are statistically significant at conventional levels $(\mathrm{t}=-3.54$ and $\mathrm{t}=-2.50$, respectively).

Next we investigate whether the differences between pre-announcing and non-preannouncing firms are due to firm-specific differences by analyzing the announcement period returns in 1978-1997 for firms that pre-announced earnings in 1998-2001 (when these firms are not likely to have pre-announced earnings). As reported in Row 4 of Table 3A, the announcement period return in 1978-1997 for those firms that did preannounce in 1998-2001 are 0.54 percent $(t=4.57)$ using the firm as its own benchmark and 0.14 percent $(t=4.02)$ relative to non-announcing firms. The announcement period returns in 1978-1997 for firms that did not pre-announce earnings in the 1998-2001 are $0.56(t=4.96)$ and $0.16(t=3.52)$, respectively (Row 5$)$. However, as reported in Row 6 of Table $3 \mathrm{~A}$, the difference across these two portfolios is not statistically significant at conventional levels. Thus, we find no evidence that the lower announcement period return of pre-announcing firms is due to firm-specific characteristics. 
Jointly, these results reported in Table $3 \mathrm{~A}$ imply that pre-announcements reduce the announcement-period returns. Since pre-announcements are likely to reduce the earnings announcement risk, we interpret these results as being consistent with the presence of an announcement period premium.

However, managers may have decided to pre-announce in response to greater information leakage. We address this issue next by investigating whether the impact of pre-announcements on announcement period returns is significant after controlling for the differences in the amount of information that was available prior to the earnings announcements.

There exists at least one alternative explanation for the results reported in Table 3A. Specifically, the changing informativeness of earnings announcements, relative to other sources of information may account for the varying announcement premium over time. To further explore this hypothesis, we compute a metric which we term the Relative Information Content (RIC), which captures the informativeness of the earnings announcements across firms over and over time. Relying on Beaver (1968), we define RIC as the volatility of stock returns in the announcement periods relative to the volatility in non-announcement periods. ${ }^{10}$ Specifically, for each firm-quarter we define the relative information content of an announcement $\left(R I C_{j q}\right)$ as the ratio of the sum of squares of returns in the announcement period relative to the sum of squares of returns in the entire quarter, or:

\footnotetext{
${ }^{10}$ The measure we use focuses on the relative, rather than the absolute, informativeness of financial disclosures. See Brown, Lo and Lys (1999) for a discussion of whether financial statements became more informative over time.
} 


$$
R I C_{j q}=\frac{\sum_{t \in A_{j}}\left[R_{j, t \in A_{j}}-\bar{R}_{j q}\right]^{2}}{\sum_{t \in q_{j}}\left[R_{j, t \in q_{j}}-\bar{R}_{j q}\right]^{2}}
$$

where for firm $j$ and quarter $q, A_{j}$ represents the three day announcement period and $q_{j}$ represents the entire quarter, commencing on day +2 relative to the $q-1$ earnings announcement and ending on day +1 of quarter $q$ 's earnings announcement. Since the number of days between quarterly announcements varies, we normalize (1) by dividing the denominator by the actual number of days and multiplying by 63 (the average number of trading days in a quarter).

We perform two tests to investigate whether changes in the relative information content of earnings is related to the announcement period premia. First, we divide the sample into three groups based on RIC and compare the difference in premia between the high and low RIC portfolios. The results (untabulated) indicate that the premia are significantly higher for the high RIC portfolio, both when we use the firm as its own control $(t=28.14)$ and when we use non-announcing firms as the benchmark $(t=28.16)$. Second, we compute the correlation between RIC and the announcement period premia, and obtain positive and significant (at the 1 percent level) correlations for both benchmarks. These results support the claim that the higher the information content of earnings announcements relative to all other sources of information (i.e., the higher the risk associated with the announcements), the higher will be the announcement premia.

To provide a more formal analysis of the impact of the disclosure environment on the announcement premia, we estimate the following regression to measure the effect of preannouncements and the informativeness of earnings on the earnings announcement premia: 


$$
A P_{j q}=a+b \times R M_{j q}+c \times \operatorname{PreAnn}_{j q}+d \times R I C_{j q}+\varepsilon_{j q}
$$

where for security $j$ and quarter $q, A P_{j q}$ represents the announcement premium (measured with respect to the two benchmarks); $R M_{j q}$ is the value-weighted CRSP return on the market on the announcement period (thus the coefficient $b$ measures the extent to which the announcement day premium reflects beta risk); $\operatorname{PreAnn}_{j q}$ is a dummy variable that equal 1 if a company made a pre-announcement in that quarter, and 0 otherwise; and $R I C_{j q}$ is the relative informativeness measure. We expect a negative association between $\operatorname{PreAnn}_{j q}$ and $A P_{j q}$, and a positive association between $R I C_{j q}$ and $A P_{j q}$.

Table 3B summarizes the results of regression (2). ${ }^{11}$ Column (1) reports the results when the announcement premium is measured using the firm's own returns on nonannouncement dates as a benchmark, and Column (2) reports the results when the announcement premium is measured using non-announcing firms' returns on announcement dates as a benchmark. ${ }^{12}$

The results of the multivariate analysis are consistent with the univariate results. We find that for both the benchmarks, the coefficient estimate corresponding to PreAnn $_{j q}$ is negative and significant $(-2.16, \mathrm{t}=-5.51$ and $-2.98, \mathrm{t}=-2.50$, respectively) suggesting that the announcement risk premium is lower for firms that pre-announced their earnings. ${ }^{13}$ Similarly, for both benchmarks, the coefficient estimate corresponding to

\footnotetext{
${ }^{11}$ Our sample has only minimal time-series clustering, with the mean, median, and maximum number of firms announcing on a given day being $0.75 \%, 0.45 \%$, and $6.47 \%$ respectively. This suggests that the regression standard errors are unlikely to be understated due to cross-sectional dependence. Nevertheless we re-estimate all regressions using the Fama and MacBeth (1973) approach. As expected, none of our conclusions are changed, with only the significance of Float in Table 6A and 6B for the total sample dropping from significant at the $1 \%$ level to significant at the $5 \%$ level.

${ }^{12}$ As mentioned earlier, we conduct the tests both for the sample of on-time announcers, and for the sample of on-time and late announcers. The results for both these are similar and we only report the results for the latter sample.

${ }^{13}$ Consistent with the univariate results, the PreAnn dummy variables have the same order of magnitude as the intercepts, indicating that the announcement premium is actually zero for pre-announcing firms.
} 
$R I C_{j q}$ is positive and significant $(7.77, \mathrm{t}=23.92$ and $6.18, \mathrm{t}=15.19$, respectively) supporting the argument that greater is the information content in the earnings announcements, higher is the announcement risk premia. ${ }^{14}$ Finally, the market coefficient $b$ is positive and highly significant both in Columns (1) and (2) suggesting that earnings announcements have a higher systematic risk than nonannouncement periods.

In summary, our analysis indicates that the earnings announcement premia are significantly lower for firms that pre-announce earnings, and are significantly higher for firms with more informative earnings announcements. Given that the disclosure environment has changed over the time period examined, we expect the premia to have changed over time accordingly. We present the analysis of the trend in the announcement premia next.

\subsection{Persistence of Announcement Premia}

We investigate whether the premia documented in Table 2 persisted over time by regressing the premia on a time trend and a constant (results not tabulated). The constant is 0.05 percent $(t=9.13)$ and the slope is $0.00007(t=7.87)$. These results indicate that the average premium has been increasing over the sample period. The result is somewhat surprising given the fact that the disclosure environment for firms has been improving over the years. Thus, despite the increases in disclosures, there has been also an increase

\footnotetext{
${ }^{14}$ In order to ensure that the above results are not being driven by unobservable characteristics of firms that pre-announce in this period but are a function of the pre-announcement, we repeat the analysis for the period prior to 1998, and include a dummy variable for the firms that pre-announced in the 1998-2001 period. In unreported results we find that the dummy variable is not significant, which provides greater confidence in the above results.
} 
in the premia over time. This implies that there exist other, as yet unexplained, components that contributed to persistence of and increase in the earnings announcement premia.

Having established the continued existence of significantly higher returns on earnings announcement dates, in the following section we focus on the question: how much risk do earnings announcements add to the risk of a well-diversified portfolio?

\section{Risk-Return Trade-Off: Are Earnings Announcements Worth the Risk?}

To investigate the risk-return trade-off of earnings announcements, we compute the daily returns on three value-weighted portfolios. As before, we focus only on the on-time and late announcers. The first portfolio consists of all sample firms with available data. For each trading day, the second portfolio includes only firms for which the particular announcement day does not fall within their quarterly earnings announcement window (days $-1,0$, and +1 relative to the earnings announcement). The third portfolio consists exclusively of announcing firms for the three-day announcement period. Thus, on any given day, the third portfolio may contain firms which either announced on that day, the preceding or the following day. However, on some days, very few firms announced, resulting in an announcer portfolio of only one or two securities. For example, of the 5,464 trading days in the sample period, 211 trading days included none of the three-day announcement periods for any of the sample firms. Moreover, while announcement periods overlapped, for an additional 1,014 trading days, the market capitalization of the announcing firms comprised less than 0.1 percent of the sample. Therefore, we construct four announcer portfolios: portfolio (1) consists of trading days which include at least one 
firm's announcement period; portfolios (2), (3), and (4) consist of trading days where the market capitalization of the announcers is at least 0.1 percent, 0.5 percent, and 1.0 percent of the market capitalization of the sample firms, respectively. To allow a meaningful comparison, all portfolios are value-weighted and 100 percent invested in the respective securities. ${ }^{15}$

Our results are reported in Table 4. Column (1) reports the results for all 5,253 trading days which include a three-day announcement period of at least one announcing firm. Columns (2), (3) and (4) summarize the results for portfolios (2), (3) and (4), respectively. The average combined market capitalization of the announcing firms is 1.199 percent for the entire sample period. This figure increases to 1.924 percent for portfolio (2), 2.725 percent for portfolio (3) and to 3.512 percent for portfolio (4).

The first question we analyze is, by how much would an investor with perfect foresight of the announcement date reduced his/her portfolio risk by holding a portfolio consisting entirely of non-announcers. The next three rows report the value-weighted returns for the entire sample, each of the four announcer portfolios and each of the corresponding non-announcer portfolios. The results indicate that by excluding announcing firms, the average daily portfolio returns decline between 3.1 percent (from 0.097 percent to 0.094 percent) and 3.3 percent (from 0.091 percent to 0.088 percent), respectively. Comparing announcer- and non-announcer portfolios indicates that the announcer portfolios' returns are between 32.95 percent $(0.117 / 0.088-1)$ and 68.09 percent $(0.158 / 0.094-1)$ higher than the returns of the corresponding non-announcer portfolios.

\footnotetext{
${ }^{15}$ Notice, however, that the resulting analysis does not correspond to an implementable trading strategy because we exclude days on which either no firms announced, or days when less that $0.1,0.5$, or 1 percent of the sample firms (by market capitalization) announced
} 
Next we analyze portfolio risk. The results in the next three rows indicate that excluding announcers from the entire portfolio reduces the portfolio standard deviation between 3 percent (from 0.9371 to 0.9081 ) and 7.1 percent (from 1.021 to 0.9423 ). While excluding announcers reduces the risk of the entire portfolio, the standard deviations of the announcer portfolios is significantly (at the 5 percent level or better) larger than the standard deviation of the corresponding non-announcer portfolios. However, the differences in risk between announcer- and non-announcer portfolios decline as we focus on announcer portfolios on days when a relatively large fraction of firms announced. While holding the announcer portfolio rather than the entire portfolio increases the risk by 137.53 percent for all announcers, this increase declines to 39.4 percent when we focus on the 1,572 trading days when the market capitalization of the announcing firms exceeds 1 percent of the market capitalization of the sample. ${ }^{16}$ In fact, the standard deviation of the announcer portfolio is 48.81 percent higher than the standard deviation of the entire portfolio when we limit the announcer portfolio to days where at least 5 percent of the sample (by market capitalization) announced. The corresponding risk of the non-announcer portfolio is 6.55 percent lower than that of the entire portfolio. Also for this market capitalization, the standard deviation of the announcer portfolio is 149 percent of the standard deviation of the entire portfolio, and the corresponding risk of the non-announcer portfolio is 93 percent of the standard deviation of the entire portfolio. This is surprising, since the risk of the announcer portfolio does not seem to converge towards the risk of the non-announcer portfolio (see

\footnotetext{
${ }^{16}$ This effect is most likely due to diversification in the announcers portfolios: as indicated above 15.3 percent $(803 / 5253)$ of the trading days of announcer portfolio (1) include very few firms (typically one or two), resulting in a market capitalization of less than 0.1 percent of the sample (the average market capitalization of the announcers portfolio on those 803 trading days is 0.0252 percent of the sample).
} 
Figure 1 for a graphical depiction). Recall that Fama's 1986 experiment indicates that portfolios of approximately 15 securities converge towards the risk of a fully diversified portfolio.

So is the increase in return worth the risk? To answer this question, we compute the Sharpe ratios for the announcer and non-announcer portfolios. Two results are noteworthy. ${ }^{17}$ First, comparing the non-announcers portfolios to the corresponding entire portfolios indicates that the Sharpe ratios always decline when we exclude the announcers by between 1.13 percent and 1.55 percent. Second, the Sharpe ratios of the announcer portfolios exceed the Sharpe ratios of the non-announcers portfolios, once sufficient diversification is present in the announcer portfolios (portfolios 3 and 4). This indicates that excluding announcers reduces the return-risk tradeoff. Finally, we compute Jensen's Alpha for the announcer portfolios. ${ }^{18}$ The results, reported in the last three rows of Table 4 indicate that announcer portfolios (2), (3) and (4) earn a significant excess return of between 0.038 percent and 0.053 percent per day (significant at the 10 percent level for announcer portfolio (2) and at the 5 percent level for announcer portfolios (3) and (4)). Ignoring transactions costs, these daily excess returns correspond to annualized excess returns between 10.0 percent and 14.1 percent.

The persistence of the above excess returns is puzzling given the assumption that markets are efficient. Shleifer and Vishny (1997) suggest that documented stock market anomalies may exist because arbitrageurs fail to exploit them due to constraints on their

\footnotetext{
${ }^{17}$ The Sharpe ratio is defined as the ratio of the portfolio excess return to the portfolio standard deviation, i.e., Sharpe Ratio $(P)=\frac{R_{P}-R_{F}}{\sigma\left(R_{P}\right)}$, where $R_{P}, R_{F}$ and $\sigma\left(R_{P}\right)$ are, respectively, the portfolio return, the riskfree rate and the standard deviation of the portfolio return.

${ }^{18}$ Jensen's Alpha is defined as the intercept in a regression of a securities excess return (return minus riskfree rate) on the market's excess return.
} 
ability to raise risk capital. They predict that volatility acts as a deterrent and limits arbitrage activities resulting in the continuing presence of stock market anomalies. This leads to our next research objective, which is to investigate whether an explanation for the existence of the announcement premia anomaly is that limits to arbitrage makes it difficult for investors to exploit this anomaly.

\section{Limits to Arbitrage and the Persistence of Announcement Risk Premia}

We use five proxies to capture the costs of executing arbitrage transactions for each firm $j$ and quarter $q$ : idiosyncratic risk (Div_Risk $k_{j q}$ ), bid-ask spread $\left(\right.$ Spread $_{j q}$ ), trading volume $\left(\right.$ Volume $\left._{j q}\right)$, float $\left(\right.$ Float $\left._{j q}\right)$, and the concentration of announcing firms $\left(\right.$ Weight $\left._{j q}\right){ }^{19}$

Following Mashruwala, Rajagopal, and Shevlin (2004), Wurgler and Zhuravskaya (2002), and Pontiff (1996) we use the idiosyncratic part of a stock's volatility to proxy for the absence of close substitutes while assuming arbitrage positions. Idiosyncratic risk is relevant to arbitrageurs because arbitrageurs can hold relatively few positions at a time due to limited capital. Several papers (e.g., Pontiff 1996; Shleifer and Vishny 1997; Wurgler and Zhuravskaya 2002; Ali, Hwang and Trombley 2003) that explore explanations related to barriers to arbitrage make similar assumptions. Thus we predict that the higher the idiosyncratic risk associated with a firm, the harder it will be for arbitrageurs to diversify the risk. We measure idiosyncratic risk as the residual variance from a regression of firm-specific stock returns on the value-weighted CRSP stock index for 12 months preceding the quarterly earnings announcement.

\footnotetext{
${ }^{19}$ The bid-ask spread, volume and float have been commonly used in the literature as proxies for limits to arbitrage, e.g., Ali, Hwang, and Trombley (2003).
} 
The bid-ask spread $\left(\right.$ Spread $\left._{j q}\right)$ captures a large portion of the round-trip transactions costs. We measure Spread $_{j q}$ in the announcement window by computing the average daily bid-ask spread scaled by the mid-point of the spread reported by CRSP for each firm and quarter.

The variable Float $_{j q}$ measures the number of shares that are available for trading in a particular stock. Depending on the nature of investors and the characteristics of the firm, certain stocks may have fewer shares that are actively traded in the market. Arbitrageurs would then be limited in their ability to take positions if there were not enough floating stock available for a particular firm. We measure Float $_{j q}$ as the average trading volume of a firm in each quarter scaled by the average shares outstanding for the firm.

The variable Volume $_{j q}$ is a proxy for the impact of arbitrageurs' taking advantage of the premia. For each firm and quarter, we measure Volume $_{j q}$ as the average of the daily trading volume in the earnings announcement window reported by CRSP. By purchasing the stock, arbitrageurs would drive down the premia. Thus, we expect a negative association between Volume $_{j q}$ and the observed announcement-period premia. Note that volume is also a proxy for the arrival of new information (Beaver 1968). Thus, absent arbitrage, volume will be positively correlated with the announcement-period premia if volume is indicative of the arrival of new information.

Our final variable, Weight $t_{j}$, represents the market capitalization of all firms announcing earnings concurrently with firm $j$. We include $W e i g h t_{j q}$ as a measure of the number of arbitrage positions available on a given day. Since arbitrage capital is likely to be limited, higher values of a Weight $_{j q}$ imply that a given arbitrage capital is spread 
across more deals, leaving a larger portion of the announcement-period return unarbitraged. ${ }^{20}$ All other variables are as defined before.

Table 5 reports the correlations among these independent variables for the entire sample period (above the main diagonal) and for the 1998-2001 period when we have information regarding pre-announcements (below the main diagonal). The five arbitrage variables are significantly correlated in the expected directions, but have fairly low correlations with each other. We estimate the following pooled time-series, crosssectional regression for both the sample of on-time announcers and of on-time and late announcers:

$$
\begin{aligned}
A P_{j q}= & a+b \times R_{j q}+c \times \text { Div }_{-} \text {Risk }_{j q}+d \times \text { Spread }_{j q}+e \times \text { Volume }_{j q} \\
& +f \times \text { Float }_{j q}+g \times \text { Weight }_{j}+h \times \text { PreAnn }_{j q}+k \times \text { RIC }_{j q}+\varepsilon_{j q}
\end{aligned}
$$

If limits to arbitrage are a driving force for the observed announcement premium, then controlling for the other factors that affect the announcement premium, firms with higher values for Div_Risk $k_{j q}$, higher values for $\operatorname{Spread}_{j q}$, lower values for Volume $_{j q}$, lower values for Float $_{j q}$, and higher values for Weight $_{j q}$ will have higher premiums. As before, we estimate regression (3) using both each firm's return during its non-announcement periods as a control as well as the returns for non-announcers on the announcement days as a control.

The results are reported in Panels A and B of Table 6 (the results for both benchmarks are very similar, so we only discuss the results in Panel A and point out differences

\footnotetext{
${ }^{20}$ An alternative metric for concentration of announcers could be constructed by counting the total number of firms that announced as a percentage of all the sample firms traded on that day (equal-weighted measure of clustering). This metric is frequently used in the literature (Chambers and Penman 1984, Brown, Clinch and Foster, 1992). This equal-weighted metric overemphasizes firms with small capitalizations and hence is not representative for investors holding diversified portfolios.
} 
whenever they exist). ${ }^{21}$ Further, we repeat the above analysis by using the 1998-2001 sub-sample where we have data on pre-announcements of earnings (the preannouncement sample). The results corresponding to the total sample are discussed first.

As expected, Div_Risk $k_{j}$, has positive and significant coefficient indicating that announcement premium is higher for firms with higher idiosyncratic risks. As expected, the coefficient estimate for Spread $_{j q}$ is positive and significant, indicating that the announcement premium is higher for firms with a greater risk of information asymmetry and higher trading costs. The coefficients for Volume $_{j q}$ and Float $_{j q}$ are negative and significant, indicating that announcement premium is higher for firms where there is usually not a high level of trading among investors holding the stock and when there is not enough floating stocks available (the coefficient on Float $_{j q}$ is not significant for the on-time sample when the returns for non-announcers on the announcement days is used as a control).

Consistent with the limits to arbitrage hypothesis, the coefficient on Weight ${ }_{j q}$ is positive and significant, indicating (limited) arbitrage capital is not sufficient to exploit the premia when there are numerous available arbitrage positions. Finally, consistent with the earlier results, the coefficients on $R I C_{j q}$ and $R M_{j q}$ are positive and significant, indicating that premia are higher when there the information content of the earnings announcements (relative to other sources of information) is high and that earnings announcements have a higher $\beta$-risk relative to non-announcement days (Ball and Kothari, 1991).

\footnotetext{
${ }^{21} \mathrm{We}$ also estimate regression (3) by replacing $R I C_{j q}$ with the variance in the three-day announcement period. The results are similar to those obtained on using $R I C_{j q}$.
} 
Next, we repeat the analysis for the 1998-2001 subsample where we have information on pre-announcements. The correlations among the variables used for this sample are reported in Table 5 below the main diagonal. As in the previous case, the five arbitrage variables are significantly correlated in the expected directions with each other, but the magnitudes of the correlations are fairly low.

The results for the pre-announcement sample reveal that the dummy variable $\operatorname{PreAnn}_{j q}$ has a negative and significant coefficient, indicating that pre-announcers have a lower announcement premium. The variables Div_Risk $k_{j q}$, Volume $_{j q}$, Spread $_{j q}$ and Weight $_{j q}$ continue to have the expected signs and are significant at conventional levels in explaining the announcement premium. However, the coefficient on Float $_{j q}$ is not statistically significant at conventional levels. The coefficient estimates for $R I C_{j q}$ and $R M_{j q}$ also continue to have positive and significant coefficients. Thus, overall, our evidence supports the hypothesis that the continued existence of the announcement premium is related to the difficulty that arbitrageurs face in trying to exploit the anomaly.

As an additional sensitivity test, we re-estimate the regressions in Tables $6 \mathrm{~A}$ and $6 \mathrm{~B}$ by including size as a control variable (defined as the market value of equity). Ball and Kothari (1991) find that smaller firms have larger announcement premia. While the coefficient of size is negative and significant at the 5\% level, inclusion of this variable does not materially affect any of our variables of interest.

\section{Summary and Conclusions}

This paper extends the literature which documents that stock returns on earnings announcement days are higher than returns on non-announcement days. We investigate 
the existence and the magnitude of the announcement premia after controlling for the timing of the announcements and the disclosure environment. We also examine whether the increased risk on earnings announcement days is justified by the increased return on those days. Finally, we investigate whether the limits to arbitrage theory explains the continued existence of the earnings announcement premia.

Our results can be summarized as follows. First, our analysis establishes the existence of an announcement premia even after controlling for the timing of earnings announcements (early, on-time or late announcements). However, our evidence also suggests that the premia documented in prior research was overstated. Second, we find that the premia are significantly lower for firms that pre-announce earnings and are significantly higher for firms with more informative earnings announcements. Both of those results are consistent with the presence of an announcement risk premium.

Next, we find that a portfolio strategy of excluding announcers from a dailyrebalanced market portfolio reduces the standard deviation of the portfolio. However, this strategy also reduces the Sharpe ratio, which indicates that excluding announcers reduces the return-risk tradeoff. Moreover, returns on earnings announcement dates "earn" significantly positive Jensen's Alphas, corresponding to an annualized return between 10 percent and 14 percent. Finally, we document that announcement-period premia are positively correlated with the costs to arbitrage and the number of available arbitrage opportunities. Jointly, our evidence is consistent with limits to arbitrage being one explanation of the continued existence of the premia.

While prior research has consistently documented a higher return on scheduled information release dates, there has not been any direct evidence on whether those higher 
returns represent announcement-risk premia. We contribute to this literature by providing evidence that the premia are dramatically reduced when the announcement risk is reduced through pre-announcements. Additionally, we provide evidence indicating that the continued presence of this premia result from limits to arbitrage. Jointly, these two findings are consistent with the view that the announcement period returns, indeed, constitute compensation for bearing announcement risk. 


\section{Appendix - Analysis and Prediction of Corporate Earnings Announcement Dates}

In this appendix we develop a model of the quarterly earnings announcement dates. In practice firms can announce earnings on a particular day of the week or choose the day of the week based on the content of news to be disclosed (Watts, 1978; Patell and Wolfson, 1982; Penman, 1987; Ball and Bartov, 1995; Brown, Clinch and Foster, 1992). Additionally firms may follow complicated algorithms such as "the first Tuesday, three weeks following the end of the fiscal quarter," and it may not be easy to detect those rules because actual announcement dates often deviate from expected announcement dates. ${ }^{22}$

Various models for prediction of earnings announcement dates have been used in the literature. Givoly and Palmon (1982) use four alternative models to compute the expected announcement date. ${ }^{23}$ In particular, the first model uses a firm's prior period announcement date as a proxy for the current year's announcement date. Chambers and Penman (1984) and Begley and Fischer (1998) use the same model to analyze quarterly as well as annual earnings announcements. ${ }^{24}$ However, this approach results in measurement errors, for any announcement that deviates from the 'normal' disclosure strategy. For example, if $\mathrm{Q}_{\mathrm{t}}$ were to be late, then $\mathrm{Q}_{\mathrm{t}+4}$ is likely to be classified as early, even when in reality it were announced 'on time.' Similar problems are present with the other models used in the literature. Essentially, the use of any expectation model that relies on actual announcement dates introduces measurement error to the analysis.

\footnotetext{
${ }^{22}$ We thank the referee for pointing this out.

${ }^{23}$ Analysis in Givoly and Palmon (1982) is based on the reporting lag relative to the fiscal year end, rather than the reporting date. However, because the fiscal year end does not vary in their analysis, there is a oneto-one relation between the expected reporting lag and the expected announcement date.

24 Chambers and Penman (1984) use two additional models to estimate the expected earnings announcement date. They report that their results were not sensitive to which model they used.
} 
To develop the expected announcement date model we analyzed the distribution of actual earnings announcement dates. ${ }^{25}$ First, the distribution of the fourth quarter announcement days differs from those of the preceding three fiscal quarters. While using separate models for Q4 and for the other three quarters (Q1, Q2 and Q3) could be efficient, the expected announcement dates for the first three fiscal quarters would be more precise (by virtue of a larger sample size) and possibly affect some of the subsequent analyses. Therefore, we decided to estimate a separate model (by firm) for each of the four fiscal quarters. Second, there is an upward trend in the announcement dates for Q1 through Q3 and an increase in the standard deviation of the Q4 announcement dates. To account for these over-time changes in the distribution of the announcement dates we divide the 24 year period into six four-year sub-periods.

For each sample firm and each fiscal quarter, we use the median announcement date as the proxy for the expected announcement date. We select the median because this statistic is least likely to be affected by individual deviations for the normal disclosure schedule. For each firm and each quarterly earnings announcement, we compute the median announcement date for each four-year sub-period. Each quarter is divided into 63 trading days. Using the quarterly earnings-announcement data from COMPUSTAT we identify each firm-quarter earnings-announcement date with the day of the quarter (i.e., day 1 to day 63). For each sample firm and each fiscal quarter, we compute the median day of announcement $\left(\operatorname{Med}_{j q}\right)$.

\footnotetext{
${ }^{25}$ Detailed results of the analysis are available from the authors and are not reported here in the interest of brevity.
} 
Using the median as a proxy for the expected announcement date, we compute the deviation from the expected announcement day $\left(\operatorname{Dev}_{j q}\right)$ as the absolute difference between the actual announcement day and the median announcement day:

$$
D e v_{j q}=\left|D_{j q}-\operatorname{Med}_{j q}\right|
$$

where for firm $j$ and quarter $q, D_{j q}$ represents the actual announcement day. Thus, $D e v_{j q}=0$ corresponds to firm $j$ having announced quarter $q$ earnings on the expected day, $D e v_{j q}=1$ represents instances where corporations have announced on either a day earlier or a day later than expected, etc.

Overall, in our sample 39.26 percent of the firm-quarter announcements are on the expected announcement day, and 62.22 percent are within one day of the expected date. In fact, 86.64 percent of the firm-quarter announcements fall into the 11-day window centered on the expected announcement day. The announcement dates for the first three fiscal quarters are more predictable than the announcement dates for the fourth fiscal quarter. For the first three fiscal quarters, the percentages of announcements that are released on the expected date range from, 39.90 percent (Q1) to 39.71 percent (Q3), while approximately 64 percent are released in the three-day window centered on the expected announcement date. In contrast, only 37.54 percent of Q4 announcements are on the expected release date, and 57.14 percent are within one day of the expected release date.

To investigate the sensitivity of our proxy to the length of the estimation period we also use four sub-periods (of 6 years each) and one sub-period (of 24 years) to compute the expected announcement date and $D e v_{j q}$. The results indicate a drop of overall on-time announcements to 35.03 percent for four sub-periods and to 23.98 percent for one sub- 
period. The decrease in on-time announcements is most pronounced for Q4. Thus, the percentage of on-time announcements is approximately 36 percent for Q1 through Q3 for 4 sub-periods and 25.01 percent for one sub-period. In contrast, for Q4, the frequencies are 32.12 percent and 20.39 percent, respectively. We get similar results (although slightly higher on-time announcements) when we use the integral value of the mean (rather than the median) as the proxy for the expected announcement date.

Prior research documents that corporate disclosure practices have changed over time with management earnings forecasts and pre-announcements more prevalent in the late nineties. We examine patterns of on-time earnings announcements to verify whether the timing of scheduled corporate accounting disclosures has changed over the sample period. The results (not tabulated) indicate a lower frequency of on-time announcements (defined as Dev $\leq 1)$ for Q4 than for Q1 through Q3 ( $\mathrm{t}=2.23)$, a negative time trend of -0.28 percent per year for all quarters $(\mathrm{t}=-3.12)$, and a marginally significant more negative time trend for Q4 than that of the other three quarters (incremental slope $=-0.18$ percent, $\mathrm{t}=-1.37)$. 


\section{$\underline{\text { References }}$}

Ali, Ashiq, Lee-Seok Hwang, and Mark A. Trombley, 2003, Arbitrage risk and the bookto-market anomaly, Journal of Financial Economics, 69, 355-373

Ball, Ray and Brown, Philip, 1968, An empirical evaluation of accounting income numbers, Journal of Accounting Research, 6, 159-178.

Ball, Ray and Kothari, S.P., 1991, Security returns and earnings announcements, The Accounting Review, 66, 718-738

Ball, Ray and Bartov, Eli, 1995, The earnings event-time seasonal and the calendar-time seasonal in stock returns: naive use of earnings information or announcement timing effect? Journal of Accounting, Auditing and Finance, 10, Fall 1995, 677 - 698.

Beaver, William H., 1968, The information content of annual earnings announcements, empirical research in accounting: selected studies, Supplement to Journal of Accounting Research, 67-92.

Begley, Joy and Fischer, Paul, 1998, Is there information in an earnings announcement delay? Review of Accounting Studies, 3(4), 347-363.

Brown, L. and Kim, K., 1993, The association between non-earnings disclosures by small firms and positive abnormal returns, Accounting Review, 68, 668-680.

Brown, Philip, Greg Clinch and George Foster, 1992, Market microstructure and capital market information content research, Sarasota, Fla.: American Accounting Association.

Brown, Steven, Kin Lo, Thomas Lys, 1999, Use of $\mathrm{R}^{2}$ in accounting research: measuring changes in value relevance over the last four decades. Journal of Accounting and Economics 28, 83-115.

Chambers, Anne and Penman, Stephen, 1984, Timeliness of reporting and the stock price reaction to earnings announcements, Journal of Accounting Research, 22, 21-47

Chari, V.V., Ravi Jagannathan and Aaron Ofer, 1987, Seasonalities in security returns: the case of earnings announcements, Journal of Financial Economics, 21, 101-121.

Cotter, Julie, Irem Tuna and Peter Wysocki, 2002, The expectations management game: Do analysts act independently of explicit management earnings guidance? Working Paper

Fama, Eugene, F. 1986, Foundations of Finance, Basic Books, Inc: New York. 
Fama, E.F. and J. MacBeth, 1973, Risk, Return and Equilibrium: Empirical Tests, Journal of Political Economy 81: 607-636.

Fama, Eugene, and French, Kenneth, 1992, The cross-section of expected stock returns, Journal of Finance, 427-465.

Fisher, I. N., and Hall, G. R., 1969, Risk and corporate rates of return, Quarterly Journal of Economics, 83, 79-92

Givoly, Dan and Palmon, Dan, 1982, Timeliness of annual earnings announcements: some empirical evidence, The Accounting Review, 57, 486-508.

Hurdle, Gloria, 1974, Leverage risk, market structure and profitability, Review of Economics and Statistics, 56, 478-485

Kalay, Avner, and Loewenstein, Uri, 1985, Predictable events and excess returns: the case of dividend announcements, Journal of Financial Economics, 14, 423-449.

Kaznik, Ron and Lev, Baruch, 1995, To warn or not to warn: management disclosures in the face of an earnings surprise, Accounting Review, 70, 113-134.

Lev, Baruch and Penman, Stephen, 1990, Voluntary forecast disclosure, nondisclosure, and stock prices, Journal of Accounting Research, 28, 49-75.

McNichols, Maureen, 1988, A comparison of the skewness of stock return distributions at earnings and non-earnings announcement dates, Journal of Accounting and Economics, 10, 239-273.

Mashruwala, Christina, Shiva Rajagopal and Terry Shevlin, 2004, Why is the Accrual Anomaly not Arbitraged Away?, working paper

Patell, James, 1976, Corporate forecasts of earnings per share and stock price behavior: empirical tests, Journal of Accounting Research, 14, 246-276.

Penman, Stephen, 1980, An empirical investigation of the voluntary disclosure of corporate earnings forecasts, Journal of Accounting Research, 18, 132-160.

Penman, Stephen, 1984, Abnormal returns to investment strategies based on the timing of earnings reports, Journal of Accounting and Economics, 6, 165-183.

Penman, Stephen, 1987, The distribution of earnings news over time and seasonalities in aggregate stock returns, Journal of Financial Economics, 18, 199-228.

Peterson, David, R., 1990, Stock return seasonalities and earnings information, Journal of Financial and Quantitative Analysis, 25, 187-201 
Pontiff, Jeremy, 1996, Costly arbitrage: evidence from closed-end funds. The Quarterly Journal of Economics 111, 1135-1152.

Robicheck, Alexander and Myers, Stewart, 1966, Conceptual problems in the use of riskadjusted discount rates, Journal of Finance, 37, 727-730.

Scholes, Myron, 1972. The market for securities: substitution versus price pressure and the effects of information on share price. Journal of Business 45, 179-211.

Skinner, Douglas, 1994, Why firms voluntarily disclose bad news, Journal of Accounting Research, 32, 38-60.

Skinner, Douglas, 1997, Earnings disclosures and stockholder lawsuits, Journal of Accounting and Economics, 23, 249-282.

Soffer, Leonard, Ramu Thiagarajan and Beverly Walther, 2000, Earnings preannouncement strategies, Review of Accounting Studies, 5, 5-26.

Watts, Ross, 1978, Systematic "abnormal" returns after quarterly earnings announcements, Journal of Financial Economics, 6, 127-150

Waymire, Gregory, 1984, Additional evidence on the information content of management earnings forecasts, Journal of Accounting Research, 22, 703-718

Wurgler, J. and E. Zhuravskaya. 2002. Does arbitrage flatten demand curves for stocks? Journal of Business 75 (4): 583-608. 


\section{Figure 1}

Standard Deviation Announcers Portfolio Relative to the Standard Deviation of the Market Portfolio

the announcer

the announcer

portfolio / standard

deviation of the

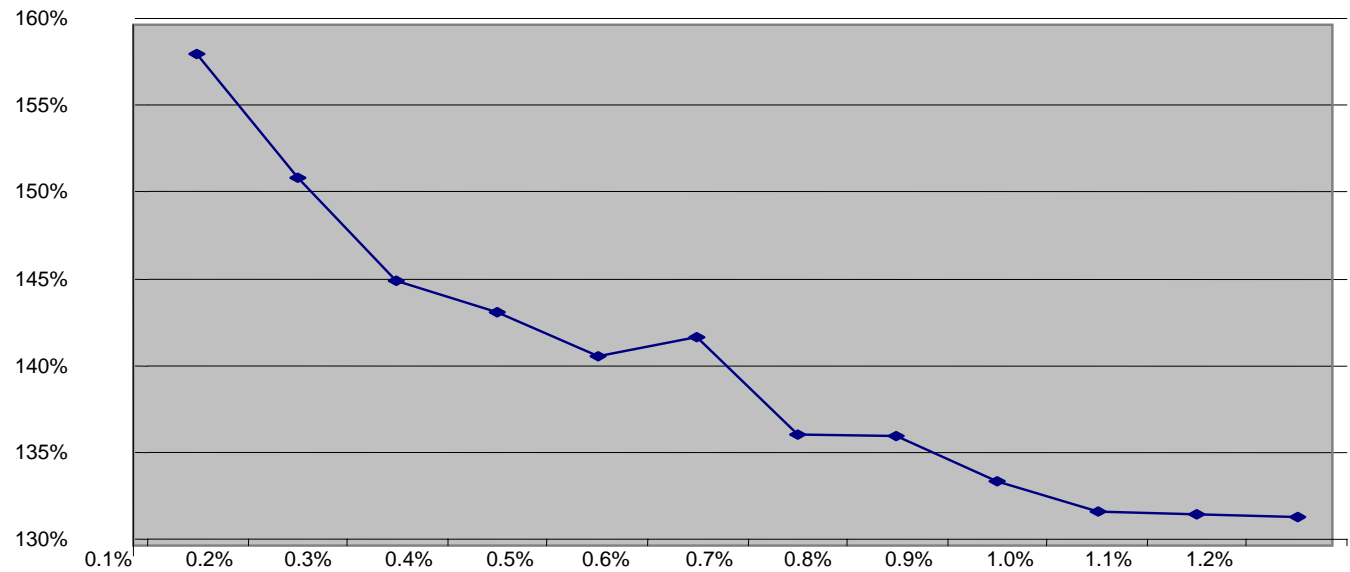

Relative Size of the Announcer Portfolio 


\begin{tabular}{|c|c|c|}
\hline \multicolumn{3}{|l|}{$\begin{array}{c}\text { TABLE } 1 \\
\text { Sample Selection } \\
\mathbf{1 9 7 8}-\mathbf{2 0 0 1} \\
\end{array}$} \\
\hline & Firms & $\begin{array}{c}\text { Firm } \\
\text { Quarters }\end{array}$ \\
\hline Earnings Announcement dates available on COMPUSTAT & 12,377 & 297,426 \\
\hline Firms with at least 10 quarterly observations & 8,493 & 275,820 \\
\hline Sample after merging with returns data on CRSP & 7,260 & 227,281 \\
\hline
\end{tabular}




\begin{tabular}{|c|c|c|c|}
\hline & $\begin{array}{r}\text { nnounceme } \\
\text { Timing of }\end{array}$ & $\begin{array}{l}\text { TABLE } 2 \\
\text { Return Premia Relati } \\
\text { e Earnings Announce } \\
\text { 1978-2001 }\end{array}$ & to the \\
\hline Portfolio & Benchmark & $\begin{array}{c}\text { Expected Announcement } \\
\text { Date }\end{array}$ & $\begin{array}{c}\text { Actual Announcement } \\
\text { Date }\end{array}$ \\
\hline & & $-1,0,+1$ & $-1,0,+1$ \\
\hline Entire Portfolio & Firm & $\begin{array}{c}0.05 \\
(2.99) \\
\end{array}$ & $\begin{array}{c}0.14 \\
(11.24) \\
\end{array}$ \\
\hline $\mathrm{N}=227,281$ & $\begin{array}{c}\text { Non- } \\
\text { Announcers }\end{array}$ & $\begin{array}{c}0.01 \\
(3.11) \\
\end{array}$ & $\begin{array}{c}0.06 \\
(5.48) \\
\end{array}$ \\
\hline Early Announcers & Firm & $\begin{array}{c}0.05 \\
(2.49) \\
\end{array}$ & $\begin{array}{c}0.29 \\
(15.18) \\
\end{array}$ \\
\hline $\mathrm{N}=85,912$ & $\begin{array}{c}\text { Non- } \\
\text { Announcers }\end{array}$ & $\begin{array}{c}-0.00 \\
(-0.93) \\
\end{array}$ & $\begin{array}{c}0.14 \\
(14.73) \\
\end{array}$ \\
\hline On-time and Late & Firm & $\begin{array}{c}0.05 \\
(4.37)\end{array}$ & $\begin{array}{l}0.05 \\
(2.53)\end{array}$ \\
\hline $\begin{array}{l}\text { Announcers } \\
\mathrm{N}=141,369\end{array}$ & $\begin{array}{c}\text { Non- } \\
\text { Announcers }\end{array}$ & $\begin{array}{c}0.01 \\
(5.14) \\
\end{array}$ & $\begin{array}{c}0.01 \\
(4.20) \\
\end{array}$ \\
\hline On-time & Firm & $\begin{array}{c}0.13 \\
(5.49) \\
\end{array}$ & $\begin{array}{c}0.13 \\
(5.49) \\
\end{array}$ \\
\hline $\begin{array}{l}\text { Announcers } \\
\mathrm{N}=56,018\end{array}$ & $\begin{array}{c}\text { Non- } \\
\text { Announcers }\end{array}$ & $\begin{array}{c}0.02 \\
(2.87)\end{array}$ & $\begin{array}{c}0.02 \\
(2.87) \\
\end{array}$ \\
\hline Late Announcers & Firm & $\begin{array}{c}-0.00 \\
(-0.31) \\
\end{array}$ & $\begin{array}{c}-0.00 \\
(-0.94) \\
\end{array}$ \\
\hline $\mathrm{N}=85,351$ & $\begin{array}{c}\text { Non- } \\
\text { Announcers }\end{array}$ & $\begin{array}{l}-0.00 \\
(0.29)\end{array}$ & $\begin{array}{l}-0.00 \\
(-6.42)\end{array}$ \\
\hline $\begin{array}{l}\text { This table reports the } \\
\text { different types of port } \\
\overline{R D}_{j, t \in A_{j}}-\overline{R D}_{j, t \notin A_{j}} \text { an } \\
\overline{R D}_{j, t \in A_{j}}-\overline{R D}_{i \notin \alpha_{t}, t} . \\
\text { premia are computed } \mathrm{f} \\
\text { announcement date ( } \mathrm{E} \\
\text { date or after the expec } \\
\text { announcement date ( } \mathrm{O} \\
\text { Announcers). }\end{array}$ & $\begin{array}{l}\text { nnouncement-day } \\
\text { olios. Two bench } \\
\text { d the return on n } \\
\text { e compute the pre } \\
\text { or all firm years ( } \\
\text { irly Announcers), } \\
\text { ed dates (On-time } \\
\text { l-time Announcers }\end{array}$ & $\begin{array}{l}\text { eturns premia and the associated } \\
\text { arks are used: the return on the } \\
\text {-announcing firms on the annou } \\
\text { a for the expected announcement } \\
\text { ire Portfolio), for those firms tha } \\
r \text { those firms that announce eithe } \\
\text { d Late Announcers), for those fir } \\
\text { and those firms that are neither ea }\end{array}$ & $\begin{array}{l}\text { statistics in parenthesis by five } \\
\text { am on non-announcement days } \\
\text { ing firm's announcement date } \\
\text { indow (days }-1,0 \text { and }+1 \text { ). The } \\
\text { innounce ahead of the expected } \\
\text { on the expected announcement } \\
\text { that announce on the expected } \\
\text { y nor on-time announcers (Late }\end{array}$ \\
\hline
\end{tabular}




\begin{tabular}{|c|c|c|c|}
\hline \multicolumn{4}{|c|}{$\begin{array}{c}\text { TABLE 3A } \\
\text { The Relation between Announcement-Return Premia, and Pre- } \\
\text { Announcements }\end{array}$} \\
\hline Row & Portfolio & $\begin{array}{l}\text { Benchmark: Firm's } \\
\text { Own Return on } \\
\text { Non-Announcement } \\
\text { Dates }\end{array}$ & $\begin{array}{l}\text { Benchmark: Non- } \\
\text { announcing Firms' } \\
\text { Returns on } \\
\text { Announcement Dates }\end{array}$ \\
\hline 1 & $\begin{array}{l}\text { Return on expected announcement } \\
\text { date for firms that pre-announced } \\
1998-2001\end{array}$ & $\begin{array}{c}0.06 \\
(2.48)\end{array}$ & $\begin{array}{c}0.05 \\
(2.38)\end{array}$ \\
\hline 2 & $\begin{array}{l}\text { Return on expected announcement } \\
\text { date for firms that did not pre- } \\
\text { announce } 1998-2001\end{array}$ & $\begin{array}{c}0.14 \\
(4.08)\end{array}$ & $\begin{array}{c}0.11 \\
(3.53)\end{array}$ \\
\hline 3 & Difference between Rows 1 and 2 & $\begin{array}{c}-0.08 \\
(-3.54)\end{array}$ & $\begin{array}{l}-0.003 \\
(-2.50)\end{array}$ \\
\hline 4 & $\begin{array}{l}\text { Return on expected announcement } \\
\text { dates in the period 1978-1997 for } \\
\text { firms that pre-announced in } 1998 \text { - } \\
\qquad 2001\end{array}$ & $\begin{array}{c}0.54 \\
(4.57)\end{array}$ & $\begin{array}{c}0.14 \\
(4.02)\end{array}$ \\
\hline 5 & $\begin{array}{l}\text { Return on expected announcement } \\
\text { dates in the period 1978-1997 for } \\
\text { firms that did not pre-announce in } \\
1998-2001\end{array}$ & $\begin{array}{c}0.56 \\
(4.96)\end{array}$ & $\begin{array}{c}0.16 \\
(3.52)\end{array}$ \\
\hline 6 & Difference between Rows 4 and 5 & $\begin{array}{c}-0.02 \\
(-1.41)\end{array}$ & $\begin{array}{c}-0.02 \\
(-1.02)\end{array}$ \\
\hline \multicolumn{4}{|c|}{$\begin{array}{l}\text { This table analyses the relation between the earnings announcement premia, and pre-announcements for the sample } \\
\text { of on-time and late announcers. Rows } 1 \text { (Row 2) reports the returns for pre-announcing (non-pre-announcing) } \\
\text { firms on expected announcement dates in the } 1998-2001 \text { period. Row } 4 \text { reports the returns on expected } \\
\text { announcement dates in the 1978-1997 for firms that eventually pre-announced earnings in the } 1998-2001 \text { period. } \\
\text { Row } 5 \text { reports the returns on expected announcement dates in the 1978-1997 for firms that did not pre-announce } \\
\text { earnings in the 1998-2001 period. }\end{array}$} \\
\hline
\end{tabular}




\begin{tabular}{|c|c|c|}
\hline \multicolumn{3}{|c|}{$\begin{array}{l}\text { TABLE 3B } \\
\text { The Relation between Announcement-Return Premia, Pre-Announcements } \\
\text { and Informativeness of Earnings } \\
\text { On-time and Late Announcers 1998- } \mathbf{2 0 0 1} \\
\mathbf{N}=\mathbf{4 0 , 2 2 4} \\
A P_{j q}=a+b \times R M_{j q}+c \times \text { PreAnn }_{j q}+d \times R I C_{j q}+\varepsilon_{j q}\end{array}$} \\
\hline & (1) & (2) \\
\hline & $\begin{array}{l}\text { Benchmark: Firm's Own Return } \\
\text { on Non-Announcement Dates }\end{array}$ & $\begin{array}{c}\text { Benchmark: Non-announcing } \\
\text { Firms' Returns on Announcement } \\
\text { Dates }\end{array}$ \\
\hline & $\begin{array}{c}\text { Coefficient } \\
\text { (t-stat) }\end{array}$ & $\begin{array}{c}\text { Coefficient } \\
\text { (t-stat) }\end{array}$ \\
\hline Constant $\times 10^{-3}$ & $\begin{array}{c}2.41 \\
(4.81) \\
\end{array}$ & $\begin{array}{c}1.13 \\
(4.01) \\
\end{array}$ \\
\hline$R M_{j q}$ & $\begin{array}{c}0.877 \\
(18.42)\end{array}$ & $\begin{array}{l}0.713 \\
(17.00)\end{array}$ \\
\hline PreAnn $_{j q} \times 10^{-3}$ & $\begin{array}{c}-2.16 \\
(-5.51)\end{array}$ & $\begin{array}{l}-2.98 \\
(-2.50)\end{array}$ \\
\hline$R I C_{j q} \times 10^{-2}$ & $\begin{array}{c}7.77 \\
(23.92)\end{array}$ & $\begin{array}{c}6.18 \\
(15.19)\end{array}$ \\
\hline$F$ & $\begin{array}{c}473.28 \\
(<0.0001)\end{array}$ & $\begin{array}{c}206.80 \\
(<0.0001)\end{array}$ \\
\hline$R^{2}$ & 0.035 & 0.026 \\
\hline \multicolumn{3}{|c|}{$\begin{array}{l}\text { This table analyses the relation between the earnings announcement premia, pre-announcements and the } \\
\text { informativeness of earnings announcements for the sample of on-time and late announcers. For Column }(1) \text { the } \\
\text { dependent variable, } A P_{j q} \text {, is the return on announcement dates minus the return of the firm on non-announcing } \\
\text { days; and for Column }(2) \text { it is the return on announcement dates minus the return on the same date for non- } \\
\text { announcing firms. The table reports the regression coefficients and the associated t-statistics in parenthesis. } R M_{q} \text { - } \\
\text { is the value-weighted CRSP return on the market in the announcement period; } P r e A n n n_{j q} \text { is a dummy variable } \\
\text { which takes the value of } 1 \text { if the firm made a pre-announcement in that quarter, and } 0 \text { otherwise; } R I C_{j q} \text { is the sum } \\
\text { of squared returns in the three-day announcement period divided by the sum of squared returns in the entire } \\
\text { quarter. }\end{array}$} \\
\hline
\end{tabular}




\section{TABLE 4}

\section{Analysis of Announcers and Non-announcers Daily Portfolio Returns}

\begin{tabular}{|c|c|c|c|c|c|}
\hline & \multirow{2}{*}{$\begin{array}{c}\text { (1) } \\
\text { All } \\
\text { Announcers }\end{array}$} & \multicolumn{3}{|c|}{$\begin{array}{l}\text { Include trading days with percentage of } \\
\text { announcers with market capitalization }\end{array}$} \\
\hline & & & $\begin{array}{c}(2) \\
\text { at least } 0.1\end{array}$ & $\begin{array}{c}\text { (3) } \\
\text { at least } 0.5\end{array}$ & $\begin{array}{c}(4) \\
\text { at least } 1.0\end{array}$ \\
\hline \multicolumn{2}{|c|}{ Trading Days } & 5,253 & 3,239 & 2,192 & 1,572 \\
\hline \multicolumn{2}{|c|}{$\begin{array}{l}\text { Average Market } \\
\text { Capitalization of } \\
\text { Announcing firms (\%) }\end{array}$} & 1.199 & 1.924 & 2.725 & 3.512 \\
\hline \multirow{3}{*}{ Return (\%) } & $\begin{array}{l}\text { Entire } \\
\text { Portfolio }\end{array}$ & 0.091 & 0.096 & 0.097 & 0.097 \\
\hline & $\begin{array}{l}\text { Non- } \\
\text { Announcers } \\
\text { Portfolio }\end{array}$ & 0.088 & 0.093 & 0.094 & 0.094 \\
\hline & $\begin{array}{l}\text { Announcers } \\
\text { Portfolio }\end{array}$ & 0.117 & 0.129 & 0.132 & 0.158 \\
\hline \multirow{3}{*}{$\begin{array}{l}\text { Standard } \\
\text { Deviation } \\
(\%)\end{array}$} & $\begin{array}{l}\text { Entire } \\
\text { Portfolio }\end{array}$ & 0.9371 & 0.9588 & 0.9862 & 1.021 \\
\hline & $\begin{array}{l}\text { Non- } \\
\text { announcers } \\
\text { Portfolio } \\
\end{array}$ & 0.9081 & 0.9112 & 0.9216 & 0.9423 \\
\hline & $\begin{array}{l}\text { Announcers } \\
\text { Portfolio }\end{array}$ & 2.2259 & 1.5465 & 1.4676 & 1.4233 \\
\hline \multirow{3}{*}{$\begin{array}{l}\text { Sharpe } \\
\text { Ratio }\end{array}$} & $\begin{array}{l}\text { Entire } \\
\text { Portfolio }\end{array}$ & 0.0775 & 0.0812 & 0.0797 & 0.0765 \\
\hline & $\begin{array}{l}\text { Non- } \\
\text { announcers } \\
\text { Portfolio }\end{array}$ & 0.0763 & 0.0800 & 0.0788 & 0.0755 \\
\hline & $\begin{array}{l}\text { Announcers } \\
\text { Portfolio }\end{array}$ & 0.0444 & 0.0714 & 0.0804 & 0.0953 \\
\hline \multirow{3}{*}{$\begin{array}{l}\text { Jensen's } \\
\text { Alpha } \\
\text { Announcers }\end{array}$} & Daily (\%) & 0.017 & 0.038 & 0.042 & 0.053 \\
\hline & $\begin{array}{c}\text { Annualized } \\
(\%)\end{array}$ & 4.4 & 10.0 & 11.2 & 14.1 \\
\hline & t-statistic & 0.61 & 1.84 & 2.10 & 2.48 \\
\hline \multicolumn{6}{|c|}{$\begin{array}{l}\text { This table reports results for three value weighted portfolios on days when at least one firm, at least } 0.1 \\
\text { percent, at least } 0.5 \text { percent, and at least } 1 \text { percent of firms by market capitalization, announced earnings. } \\
\text { Column (1) reports returns by including the portfolio of announcers independent of the market } \\
\text { capitalization of the announcing firms. Columns (2) through (4) report results of excluding announcers } \\
\text { when the announcers constitute at least } 0.1 \text { percent, } 0.5 \text {, percent, or } 1 \text { percent of the market capitalization of } \\
\text { the sample. The last three rows report Jensen's Alpha, the corresponding annualized returns (assuming } 250 \\
\text { trading days per annum) and the associated t-statistics of the announcer portfolio. }\end{array}$} \\
\hline
\end{tabular}




\begin{tabular}{|c|c|c|c|c|c|c|c|c|c|}
\hline \multicolumn{10}{|c|}{ Pre-announcement Sample (below the main diagonal) } \\
\hline & $A P 1$ & $A P 2$ & $R M$ & $R I C$ & Weight & Div_Risk & Spread & Volume & Float \\
\hline$A P 1$ & & $0.927^{*}$ & $0.156^{*}$ & $0.091^{*}$ & $0.013^{*}$ & 0.007 & $0.022^{*}$ & -0.005 & -0.012 \\
\hline$A P 2$ & $0.939^{*}$ & & $0.126^{*}$ & $0.123^{*}$ & $0.009^{*}$ & $0.021^{*}$ & $0.046^{*}$ & $-0.021^{*}$ & 0.005 \\
\hline$R M$ & $0.188^{*}$ & $0.101^{*}$ & & 0.004 & $0.011^{*}$ & $0.013^{*}$ & 0.009 & 0.004 & $0.011^{*}$ \\
\hline$R I C$ & $0.099^{*}$ & $0.148^{*}$ & 0.017 & & $0.029^{*}$ & $-0.089^{*}$ & $-0.267^{*}$ & $0.031^{*}$ & $0.022^{*}$ \\
\hline Weight & $0.021^{*}$ & $0.013^{*}$ & $0.031^{*}$ & $0.048^{*}$ & & $0.129^{*}$ & $0.112^{*}$ & $0.138^{*}$ & $0.041^{*}$ \\
\hline Div_Risk & 0.009 & $0.041^{*}$ & $0.027^{*}$ & $-0.097^{*}$ & $0.157^{*}$ & & $0.554^{*}$ & $-0.071^{*}$ & $-0.214^{*}$ \\
\hline Spread & $0.029^{*}$ & $0.087^{*}$ & 0.018 & $-0.328^{*}$ & $0.143^{*}$ & $0.498^{*}$ & & $-0.076^{*}$ & $-0.143^{*}$ \\
\hline Volume & -0.009 & $-0.041^{*}$ & 0.008 & $0.064^{*}$ & $0.165^{*}$ & $-0.093^{*}$ & $-0.091^{*}$ & & $0.158^{*}$ \\
\hline Float & -0.021 & 0.007 & $0.026^{*}$ & $0.042^{*}$ & $0.073^{*}$ & $-0.256^{*}$ & $-0.178^{*}$ & $0.213^{*}$ & \\
\hline \multicolumn{10}{|c|}{$\begin{array}{l}\text { * Significant at the } 1 \% \text { level } \\
\text { This table reports the Pearson correlations of the variables used in the limits to arbitrage tests for the non-pre- } \\
\text { announcement sample. } A P 1 \text { is the return in the announcement window minus the return on non-announcement dates for } \\
\text { the same firm; } A P 2 \text { is the return in the announcement window minus the return of non-announcing firms in the } \\
\text { announcement window; } R M \text { is the value-weighted CRSP return on the market in the announcement period; RIC is the sum } \\
\text { of squared returns in the three-day announcement period divided by the sum of squared returns in the entire quarter; } \\
\text { Weight represents the market capitalization of the firms announcing concurrently; Div_Risk is the diversifiable risk of a } \\
\text { security measured in the } 12 \text { month period prior to a quarter; Spread is the ratio of the high ask price minus the low bid } \\
\text { price divided by the average of the high ask price and the low bid price; Volume is the average trading volume during the } \\
\text { announcement period; Float is the average trade volume during quarter (excluding announcement window) divided by } \\
\text { total number of shares outstanding. }\end{array}$} \\
\hline
\end{tabular}




\begin{tabular}{|c|c|c|c|c|}
\hline \multicolumn{5}{|c|}{$\begin{array}{l}\text { TABLE } 6 \text { - PANEL A } \\
\text { ement Premia and the Limits to Arbitrage } \\
\text { ed on the three-day announcement period } \\
\text { 's Returns on Non-Announcement Days } \\
A_{j q}+c \times \text { Div }_{-} R i s k_{j q}+d \times S p r e a d_{j q}+e \times V_{o l u m e}{ }_{j q} \\
t_{j q}+g \times \text { Weight }_{j}+h \times \text { PreAnn }_{j q}+k \times R I C_{j q}+\varepsilon_{j q}\end{array}$} \\
\hline & \multicolumn{2}{|c|}{$\begin{array}{l}\text { Total Sample 1978-2001 } \\
\qquad N=141,369\end{array}$} & \multicolumn{2}{|c|}{$\begin{array}{c}\text { Pre-announcement Sample } \\
1998-2001 \\
N=40,224 \\
\end{array}$} \\
\hline & Coeff. & (t-stat) & Coeff. & (t-stat) \\
\hline Constant $\times 10^{-3}$ & 2.14 & $(4.25)$ & 3.07 & $(2.58)$ \\
\hline$R M_{i q} \times 10^{-1}$ & 7.71 & $(62.49)$ & 6.99 & $(27.33)$ \\
\hline Div_Risk $k_{j q} \times 10^{-4}$ & 5.75 & $(4.78)$ & 1.14 & $(3.89)$ \\
\hline Spread $_{i q} \times 10^{-3}$ & 7.47 & $(4.06)$ & 2.23 & $(5.37)$ \\
\hline Volume $_{j q} \times 10^{-10}$ & -2.81 & $(-2.42)$ & -4.23 & $(-3.33)$ \\
\hline Float $_{j q} \times 10^{-5}$ & -5.04 & $(-4.19)$ & -5.03 & $(-0.56)$ \\
\hline Weight $_{i q} \times 10^{-2}$ & 6.57 & $(3.54)$ & 2.93 & $(4.62)$ \\
\hline PreAnn $_{i q} \times 10^{-3}$ & & & -1.41 & $(-3.01)$ \\
\hline$R I C_{i q} \times 10^{-2}$ & 9.97 & $(47.42)$ & 7.13 & $(25.63)$ \\
\hline$F \quad(p$-value $)$ & 909.12 & $(<0.0001)$ & 297.96 & $(<0.0001)$ \\
\hline$R^{2} \times 10^{-2}$ & & & & \\
\hline \multicolumn{5}{|c|}{ 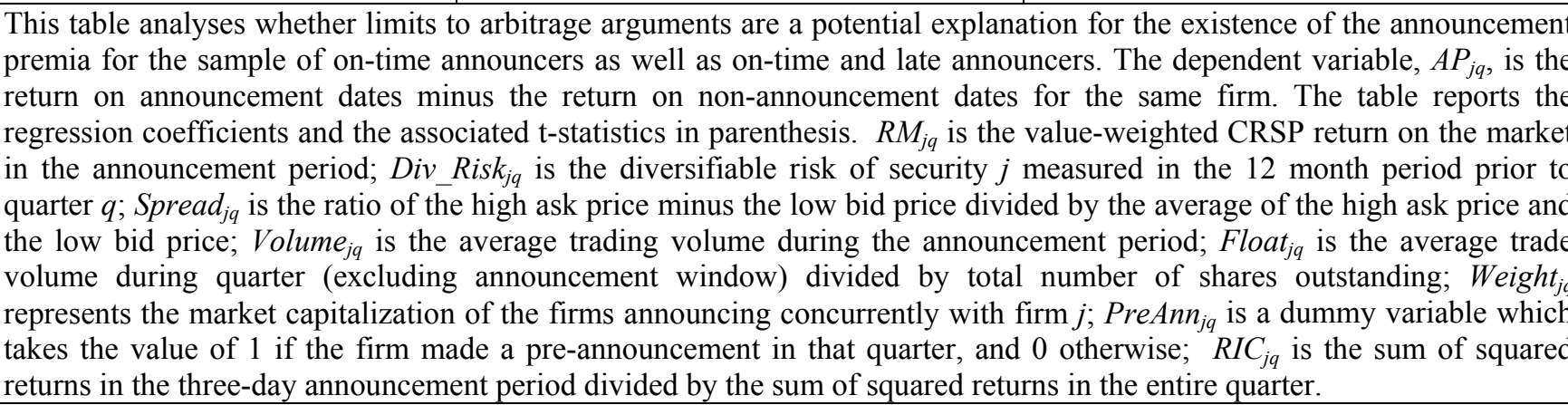 } \\
\hline
\end{tabular}




\begin{tabular}{|c|c|c|c|c|}
\hline $\begin{array}{r}\text { Earnings } \\
\text { Premiur } \\
\text { Benchmark: Ret } \\
A P\end{array}$ & $\begin{array}{r}\text { TAB } \\
\text { Icement } \\
\text { red on } \\
\text { Non-An } \\
R M_{j q}+c \times \\
o a t_{j q}+g \times\end{array}$ & $\begin{array}{l}\text { - PANI } \\
\text { mia and } \\
\text { hree-day } \\
\text { ncing Fi } \\
R i s k_{j q}+d \times \\
t_{j}+h \times P r e\end{array}$ & $\begin{array}{l}\text { mits to Arb } \\
\text { incement p } \\
\text { Announcer } \\
+e \times V_{o l u m e}{ }_{j q} \\
\times R I C_{j q}+\varepsilon_{j q}\end{array}$ & Window \\
\hline & $\begin{array}{r}\text { Total San } \\
N=\end{array}$ & $\begin{array}{l}78-2001 \\
69\end{array}$ & $\begin{array}{r}\text { Pre-announc } \\
N=40,224\end{array}$ & $\begin{array}{l}\text { Sample } \\
2001\end{array}$ \\
\hline & Coeff. & (t-stat) & Coeff. & (t-stat) \\
\hline Constant $\times 10^{-3}$ & 1.00 & $(1.12)$ & 1.12 & $(1.42)$ \\
\hline$R M_{i q} \times 10^{-1}$ & 8.94 & $(36.54)$ & 7.71 & $(29.41)$ \\
\hline Div_Risk $_{j q} \times 10^{-4}$ & 2.35 & $(4.20)$ & 1.93 & $(2.67)$ \\
\hline Spread $_{j q} \times 10^{-3}$ & 2.34 & $(1.76)$ & 2.11 & $(5.09)$ \\
\hline Volume $_{j q} \times 10^{-10}$ & -4.54 & $(-1.97)$ & -6.10 & $(-4.88)$ \\
\hline Float $_{j q} \times 10^{-5}$ & -1.15 & $(-4.81)$ & -1.65 & $(-0.49)$ \\
\hline Weight $_{j q} \times 10^{-2}$ & 2.35 & $(4.20)$ & 3.17 & $(5.07)$ \\
\hline PreAnn $_{i q} \times 10^{-3}$ & & & -2.60 & $(-5.64)$ \\
\hline$R I C_{i q} \times 10^{-2}$ & 6.91 & $(29.67)$ & 6.64 & $(24.24)$ \\
\hline$F$ (p-value $)$ & 487.21 & $(<0.0001)$ & 201.61 & $(<0.0001)$ \\
\hline$R^{2} \times 10^{-2}$ & & & & \\
\hline $\begin{array}{l}\text { This table analyses whethe } \\
\text { premia for the sample of on } \\
\text { on announcement window } \\
\text { regression coefficients and } \\
\text { announcement period; Div } \\
\text { Spread }_{j q} \text { is the ratio of the } 1 \\
\text { price; Volume }_{j q} \text { is the aver } \\
\text { quarter (excluding announ } \\
\text { capitalization of the firms a } \\
\text { firm made a pre-announce }\end{array}$ & $\begin{array}{l}\text { itrage argur } \\
\text { ers as well a } \\
\text { urn of non- } \\
\text { t-statistics in } \\
\text { diversifiabl } \\
\text { minus the lo } \\
\text { olume durin } \\
\text { w) divided } \\
\text { tcurrently w } \\
\text { quarter, an }\end{array}$ & $\begin{array}{l}\text { e a potential } \\
\text { ne and late an } \\
\text { cing firms on } \\
\text { nesis. } R M_{j q} \text { is } \\
\text { f security } j \mathrm{~m} \\
\text { orice divided } \\
\text { anouncement } \\
1 \text { number of } \\
j \text {; PreAnn } \\
\text { herwise; } R I C_{j}\end{array}$ & $\begin{array}{l}\text { for the existence } \\
\text { he dependent vari } \\
\text { ncement window. } \\
\text { eighted CRSP retu } \\
\text { the } 12 \text { month per } \\
\text { ge of the high asl } \\
\text { at } t_{j q} \text { is the averag } \\
\text { tanding; Weight } t_{j q} \\
\text { variable which tak } \\
\text { m of squared ret }\end{array}$ & $\begin{array}{l}\text { announcement } \\
P_{j q}, \text { is the return } \\
\text { ble reports the } \\
\text { e market in the } \\
\text { or to quarter } q \text {; } \\
\text { and the low bid } \\
\text { volume during } \\
\text { nts the market } \\
\text { alue of } 1 \text { if the } \\
\text { the three-day }\end{array}$ \\
\hline
\end{tabular}

